\title{
What are words worth?
}

\author{
FRANCESCA RAYNER
}

Título: sim sim não não. Trabalho de Maria Duarte, Sílvia Figueiredo e João Rodrigues a partir de John Berger e Susan Sontag. Interpretação: Maria Duarte e Sílvia Figueiredo. Violoncelo: Tatiana Leonor. Piano: Teresa Doutor. Co-produção: Maria Duarte, Sílvia Figueiredo e João Rodrigues/Culturgest. Local e data de estreia: Palco do Grande Auditório da Culturgest, 11 de Abril de 2018.

A 1983 edition of the Channel 4 television programme Voices brought together the essayists and novelists John Berger and Susan Sontag to discuss storytelling. It was a programme of contrasts: urban and rural, English and North-American, male and female and such contrasts were also evident in their approaches to storytelling. John Berger argued for a view of storytelling as the ethical recounting of a life while Sontag countered this with a modernist and post-modernist view of storytelling as the product of the author's imagination and potentially involving multiple narratives. Sitting across the table from each other, the panther-like Sontag won the contest hands down against the tense, hawk-like Berger. It was a fascinating programme about the intensity both of thought and of listening, where both protagonists formulated ideas, agreed to disagree, rewound the conversation and reformulated their thoughts.

Sim sim não não [yes yes no no] credits the Sontag/Berger interview as inspiration but takes its title from The Gospel According to Matthew: The Sermon on the Mount, where Matthew recommends not swearing by anything or anyone but rather sticking exclusively to the words yes yes no no. For Matthew, everything beyond this is "unjust". The biblical symbolism of the title might therefore seem a critique of the extended verbal exploration of storytelling by Berger and Sontag as just such an example of iniquity. Yet what binds the interview and the sermon is an interest in the process of communication. What is the role of language in communication? How does the body communicate? What do Berger and Sontag's frequent hand gestures transmit to each other and to their audience? Most significantly for this performance, what is the difference between communication on television and in the theatre?

Maria Duarte and João Rodrigues are founding members of Projeto Teatral, a theatrical project which has consistently deconstructed the 


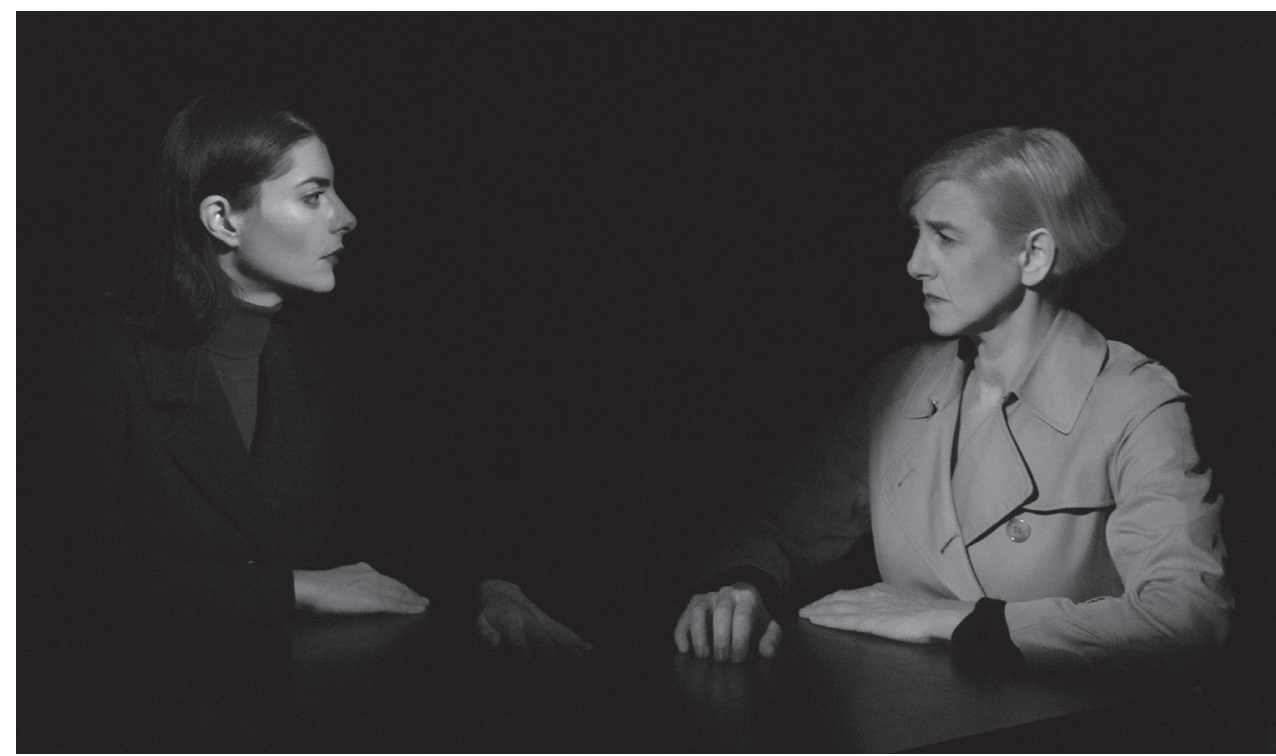

SIM SIM NÃO NÃO, UM TRABALHO DE MARIA DUARTE, SÍLVIA FIGUEIREDO E JOÃO RODRIGUES, CULTURGEST, 2018 (SÍLVIA FIGUEIREDO, MARIA DUARTE), [F] MARGARIDA RIBEIRO

constituent elements of the theatrical event through reference to the visual arts and literature. In this performance, the exploration of theatrical communication illustrated how spoken word, lighting, space, facial gestures, actor interaction and audience combine to create communication in the theatre without privileging any of these as the essence of the medium. The audience was sat on both sides of a large rectangular table in the centre of the theatre which was lit from above. Two actresses (Maria Duarte and Silvia Figueiredo) entered and circled the table for an extended period of time before taking their places at the table with a rectangle of glass separating them. Throughout the performance, the lights went up and down on the perfectly still actresses. Each time the lights went up, the actresses turned to face each other in the mirror. Sometimes their faces were separate, sometimes juxtaposed. When the lights went down, the audience heard fingers drumming on the table until the lights came on again. Your place in the audience determined which actress you saw in the mirror and which you only saw in shadow.

The repetition of these sequences was both fascinating and tedious, encouraging an interest in what might happen next as well as a desire for the repetition to end. Yet just as the audience began to give up on the performance, they were surprised with short bursts of dialogue. These were taken from the Berger/Sontag conversation and included Berger's 


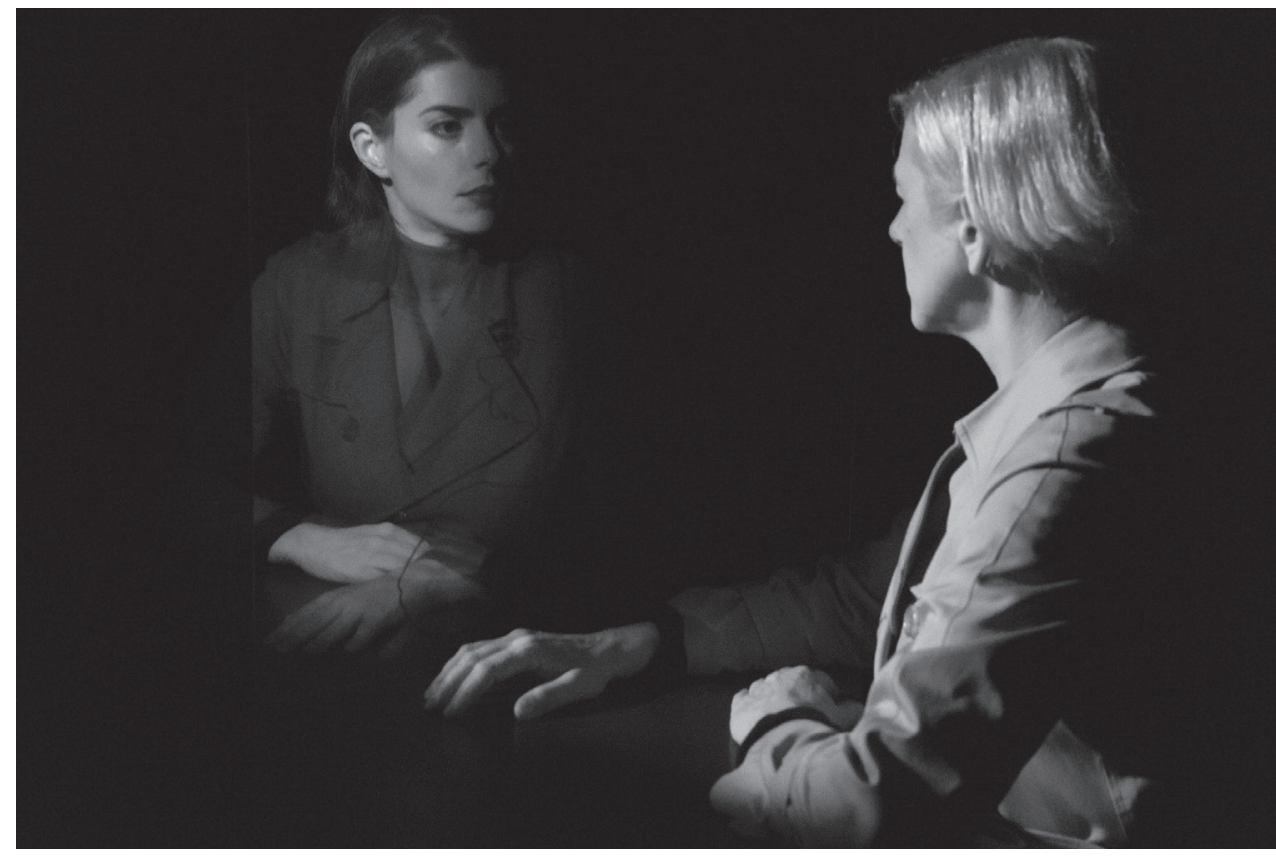

SIM SIM NÃO NÃO, UM TRABALHO DE MARIA DUARTE, SÍLVIA FIGUEIREDO E JOÃO RODRIGUES, CULTURGEST, 2018 (SÍLVIA FIGUEIREDO, MARIA DUARTE), [F] MARGARIDA RIBEIRO

notion of the writer as "death's secretary" or Sontag's counterpointing of sound ("I hear voices") as the beginning of her creative process to Berger's emphasis on sight (“I see”). They included Sontag's intriguing comment that the voices told her to seek beautiful things, convinced her that they still existed, but warned her they wouldn't be there for long. The scarcity of words in this performance made them both precious and memorable. I could remember just about every word used in the performance after it had ended.

There were also moments of live music from a piano and a cello (Teresa Doutor and Tatiana Leonor respectively). Yet it was the intensity of the stillness of the two actresses, repeating in a performative form and medium the intensity of Berger and Sontag talking and listening to each other that carried the performance. The television conversation and the theatrical performance both lasted around an hour. Although the former was about literature and the latter about the performing arts, both reaffirmed a sense of art as intense communication that removes its reader/ audience from daily experience only to heighten its value. In this dramaturgy of sensory conceptualism, the word as both sound and sense occupied a central though not dominant place in a unique theatrical event. 